\title{
Exame da tutela de urgência e da tutela de evidência no Projeto do Novo Código de Processo Civil
}

\section{Analyses of the protection of urgency and evidence in the draft of the new Civil Procedure Code}

\author{
Fernando Horta Tavares* \\ Daniel de Almeida Rocha* \\ Érica Monteiro Barbosa ${ }^{* * *}$
}

\section{Resumo}

O Projeto de Lei do novo Código de Processo Civil brasileiro tem como objetivo principal simplificar a técnica processual e trazer celeridade na tramitação dos procedimentos. Nesse contexto, a proposta do novo Código inova ao prever os institutos das tutelas de urgência e de evidência. Talvez por partir de marcos teóricos superados, a comissão faça prever várias proposições equivocadas, merecedoras de revisitação. Percebe-se uma utilização do processo cautelar e da antecipação de tutela como solução para além dos problemas que esses institutos objetivam resolver. Dessa forma, é necessário esforço para esclarecer aspectos referentes às tutelas de urgência e evidência e as decorrentes medidas de caráter satisfativo e preventivo, como previsto no novo Código, evidenciando-se as aporias existentes.

Pós-Doutoramento em Direito Constitucional pela Faculdade de Direito da Universidade Nova de Lisboa (POR). Doutor em Direito pela Pontifícia Universidade Católica de Minas Gerais - PUCMINAS. Mestre em Direito Processual pela Pontifícia Universidade Católica de Minas Gerais - PUCMINAS. Bacharel em Direito pela Universidade Federal de Minas Gerais (UFMG). Advogado e Professor. Belo Horizonte - Minas Gerais - Brasil. Email: fernandohorta@pucminas. br

* $\quad$ Mestre em Direito Processual pela PUC-Minas. Graduado em Direito pela PUC-Minas. Advogado e Empregado Público. Belo Horizonte - Minas Gerais - Brasil. E-mail: danielrocha85@gmail.com

*** Pós-graduanda em Direito Processual pelo IEC/PUC-Minas. Graduada em Direito pela PUCMinas. Advogada.Belo Horizonte - Minas Gerais - Brasil. Email: ericamb@ig.com.br 
Palavras-chave: Cautelar. Antecipação de tutela. Código de Processo Civil. Tutela de urgência. Tutela de evidência.

\section{Abstract}

This article aims to analyse the new code of civil procedure in Brazil, which has the main objective of simplifying the technical procedure and bringing speed in court procedures. In this context, the proposed new code aims to bring innovationby providing the institutes of the emergency guardianship and custody of evidence. Perhaps because of theoretical frameworks leave overcome, the committee did provide several propositions wrong, worthy of revisiting. Provisory solutions were often used, institutions and the legal protection as a solution beyond the problems that these institutes aim to solve. This time, the effort needed to clarify aspects relating to the protection of urgency and evidence, and the resulting measures of preventive character and satisfy, as envisaged in the new code, demonstrating the existing perplexities.

Keywords: Preventive. Antecipation. Trusteeship. Code of Civil Procedure. Emerengy Guardianship. Guardianship of Evidence.

\section{Introdução}

O presente artigo tem como objetivo analisar, com base em uma racionalidade crítica, os institutos das tutelas de urgência e de evidência no Projeto de Lei 166/2010, no Senado Federal, e 8046/2010', na Câmara dos Deputados, consolidadores da proposta de um novo Código de Processo Civil.

Para tanto, serão definidas com diligência as bases sobre as quais se parte para a construção das críticas, promovendo os devidos esclarecimentos para preenchimento de sentido dos conceitos trabalhados.

No decorrer do texto, as referências ao Projeto de Lei terão como base o teor do PL 8046/2010, por ele conter a redação mais recente da proposta de novo Código de Processo Civil. 
Dentro da análise do instituto da tutela de urgência, envidar-seão esforços para a análise do processo cautelar e da antecipação de tutela, estabelecendo as diferenças existentes e demonstrando qual o problema que cada um dos institutos pretende solucionar.

Para aprofundamento deste artigo, será realizado um estudo do instituto da tutela de urgência, como disposto no vigente Código de Processo Civil e no Direito Comparado, com o fim de estabelecer um panorama comparativo com o Projeto de Lei em trâmite no Congresso Nacional.

Buscar-se-á esclarecer o instituto da tutela de evidência, identificando suas bases teóricas. Pretende-se, ainda, entender qual problema o instituto se propõe a resolver e se é o mais apropriado para esse fim.

Com todos esses pontos trabalhados, preocupar-se-á em encontrar aporias nas formulações referentes aos institutos intituladores do artigo, presentes no texto do Projeto de Lei.

Com base nas aporias encontradas, formular-se-ão proposições mais adequadas para a solução dos problemas que os institutos das tutelas de urgência e de evidência tentam resolver.

\section{Bases teóricas}

Adotando a Teoria do Conhecimento Objetivo, formulada por Karl Popper (1999), conclui-se que qualquer pretensão de cientificidade do presente artigo, além do esforço de refutação acima explicitado, passa pelo necessário esclarecimento dos pontos de partida fixados como base das críticas que serão formuladas. Por isso, valer-se-á deste tópico para apresentação das bases teóricas direcionadoras de todas as proposições que serão expostas.

Em Popper (1959), é possível compreender o quanto o pensamento de Platão influenciou a forma de pensar do Ocidente, estabelecendo como metas da Ciência o alcance de verdades absolutas e imutáveis por meio do método da relação sujeito-objeto. 
Apenas a partir da reviravolta linguística promovida pela Filosofia, com destaque para os estudos de Wittgenstein, Heidegger, Gadamer, Apel e Habermas ${ }^{2}$, rompeu-se com o método sujeito-objeto para se pensar o conhecimento a partir da relação linguagem-mundo, inaugurando-se uma proposta de Filosofia da Linguagem.

Com os estudos desenvolvidos, colocou-se em xeque a proposta de Filosofia da Consciência (relação sujeito-objeto) para demonstrar a importância da linguagem, na sua função argumentativa, como construtora do conhecimento.

Tendo essa nova proposta - a Filosofia da Linguagem - como ponto de partida, foi possível verificar a falibilidade e a limitação humanas, e desmascarar o mito das verdades imutáveis, para implantar uma proposição de verdades provisórias, passíveis de testificação e refutação por todos mediante uma racionalidade crítica.

Dentro dessa concepção, o conhecimento é alcançável não pela consciência de apenas um sujeito, mas a partir da confrontação de seu pensamento com as várias outras visões de mundo dos demais sujeitos, sendo a linguagem responsável pelo intermédio intersubjetivo desse processo.

No âmbito da Ciência do Direito, os avanços propostos pela Filosofia da Linguagem alcançaram destaque com o trabalho de Habermas (1997), que, em síntese, vinculou a legitimidade do direito ao sentimento de coautoria dos seus destinatários. Assim, o direito apenas pode ser legítimo, segundo Habermas, se construído de forma intersubjetiva entre os sujeitos que sofrerão seus efeitos.

Sem adentrar nas aporias da teoria habermasiana, por não ser objeto do presente artigo, é inegável o avanço trazido pelo autor para a Ciência do Direito, exatamente por possibilitar um ponto de revisitação de várias teorias ainda vinculadas a uma proposta de Filosofia da

\footnotetext{
2 Para um aprofundamento da importância dos autores acima citados na promoção da reviravolta linguística na Filosofia, ver Oliveira (1996).
} 
Consciência. A concepção habermasiana permitiu a abertura da crítica à teoria do processo como relação jurídica.

Ao analisar as atas de audiência, a bibliografia colecionada e as obras dos insignes componentes da comissão de juristas responsável pela elaboração do anteprojeto do novo Código de Processo Civil, percebe-se a nítida adesão à teoria do processo como relação jurídica dentro da concepção instrumentalista do processo ${ }^{3}$. Como não poderia ser diferente, o texto apresentado ao Senado como resultado do trabalho da comissão retrata a adoção da citada teoria como marco teórico. Mesmo após as emendas aprovadas, o texto do projeto manteve seu viés instrumentalista.

Em obra de extrema clareza, o professor André Cordeiro Leal demonstra a fragilidade da teoria do processo como relação jurídica, apresentando uma aporia que, desde Bülow até seus atuais seguidores, ainda não foi solucionada. O erro está em conceituar jurisdição como atividade do juiz e, de forma tautológica, definir processo como instrumento de atuação da jurisdição, sem explicar como se controla a atividade jurisdicional (LEAL, 2008, p. 60).

Nesse ponto, percebe-se a influência da superada Filosofia da Consciência na formulação da teoria, uma vez que se deposita na consciência de um sujeito o exercício de aplicação do Direito mediante a utilização do processo como instrumento para se alcançar uma solução capaz de promover a paz social.

Todo esse pensamento vai de encontro aos avanços trazidos pela Filosofia da Linguagem e pela teoria discursiva habermasiana.

Ademais, ressalta-se como equívoco a inadequação da dita teoria com a compreensão acerca das implicações da adoção do Estado

3 Dinamarco (2002) desenvolveu o que se tem chamado de concepção instrumentalista do processo. Valendo-se da teoria do processo como relação jurídica, o citado autor trabalha a ideia de que o processo seria instrumento da atuação da jurisdição, implicando na atuação do juiz para além de aspectos jurídicos. Por isso, defendeu a atuação do magistrado com vista aos escopos metajurídicos do processo. 
Democrático de Direito pela Constituição da República Federativa do Brasil promulgada em 1988 (CRBF/88).

Para isso, é preciso, inicialmente, entender que as teorias são resultantes discursivas que encontram limitações na capacidade de interpretação humana, estando condicionadas aos paradigmas instalados no contexto histórico de dado momento.

Toda interpretação, assim como toda atividade humana, dá-se num contexto histórico, pressupõe paradigmas e, para usar uma expressão de Habermas, um pano de fundo de mundos da vida compartilhados, que simplesmente não podem ser, em sua totalidade, colocados entre parênteses, através de uma atividade de distanciamento ou de abstração, porque o ser humano não pode abstrairse de si mesmo, não pode fugir à sua condição de ser de linguagem; 'paradigmas', 'mundos da vida' compartilhados são condições para a interpretação, são condições para a linguagem. (OLIVEIRA, 1998, p. 132)

Acerca dos paradigmas jurídicos, Habermas (1995) apresenta importante contribuição sobre a existência de três modelos normativos de democracia, os quais o autor denomina de paradigma liberal, republicano (social) e procedimentalista, que se diferenciam nos significados atribuídos à política, à cidadania, à constituição, aos direitos fundamentais e à democracia.

Por tal razão, deve-se compreender que a teoria do processo como relação jurídica encontrou limitação no Estado Social em que prevaleceu o paradigma republicano.

O Estado Social tem como marco histórico a constituição mexicana de 1917 e a Constituição de Weimar, de 1919 (BARROSO, 2009, p. 65). Com o predomínio da visão republicana, ele surge em resposta à prevalência da atuação negativa do Estado Liberal, que proporcionou uma maximização da desigualdade material.

Assim sendo, o Estado Social buscou imputar um ideal de solidariedade e de supervalorização do âmbito público, fazendo 
prevalecer uma ideia de comunitarismo ${ }^{4}$ em que a sociedade deveria ser constituída sob um prévio consenso de valores éticos comuns (HABERMAS, 1995, p. 112). As constituições passaram a prever os denominados direitos fundamentais de segunda geração, enunciados como direitos sociais, culturais e econômicos que exigiam uma atuação positiva do Estado para sua implementação (BONAVIDES, 2002, p. 564).

No Estado Social, o exercício de cidadania seria voltado a uma práxis orientada para um entendimento mútuo e pressuporia a convergência prévia de convicções éticas. O conteúdo normativo deveria representar o consenso alcançado, partindo-se do pressuposto do entendimento anterior dos valores éticos comuns daquela sociedade (HABERMAS, 1995). Nesse sentido, Oliveira (2006a, p. 97) diz que a constituição refletiria uma ordem concreta de valores que materializam a identidade ético-cultural de uma sociedade política que se quer homogênea.

Visto isso, fica facilitado o entendimento da proposta de protagonismo judicial defendido por Bülow. Ele acastelava a sabedoria e a sensibilidade do juiz como parâmetros para a busca da vontade do povo e que poderia criar o direito mesmo contra legem (NUNES, 2010, pp. 101-102). Por certo, a vontade do povo deveria representar, numa visão republicana, a ordem concreta de valores advinda da identidade ético-cultural da sociedade política.

A desvantagem latente da visão republicana é esta: "[...] o processo democrático depende das virtudes de cidadãos devotados ao bem-estar público" (HABERMAS, 1995, pp. 111-112).

Essa crença na virtude de cidadãos devotados ao bem-estar público, no âmbito do Direito Processual, refletiu-se na falta de preocupação dos pesquisadores em explicar como se controla a

Sobre o comunitarismo, Habermas (1995, p.112) discorre: "Segundo a visão comunitarista, há uma conexão necessária entre o conceito deliberativo de democracia e a referência a uma comunidade ética concreta e firmemente integrada". 
atividade dos juízes, investindo-se no discurso de quais as qualidades necessárias para que o juiz cumpra bem sua missão ${ }^{5}$.

Nas mãos do magistrado dotado de virtudes direcionadas ao bemestar público, necessário seria um instrumento (processo) à disposição para a busca de restauração da paz social ${ }^{6}$. Por isso, o conceito de processo era vinculado à ideia de instrumento de atuação da jurisdição desenvolvida pelos magistrados. Não é outro o sentido que se pode extrair da passagem a seguir, escrita por Carnelutti, quando o autor preconiza que o processo serve para que o juízo do juiz se torne regra de conduta das partes.

O processo serve, pois, em uma palavra, para fazer que entre em juízo aqueles que não o têm. $E$, posto que o juízo é próprio do homem, para substituir o juízo de um pelo juízo de outro ou outros, fazendo do juízo de um a regra de conduta de outros, aquele que faz entrar em juízo, ou seja, aquele que fornece aos outros aquilo de que necessitam seu juízo -, é o juiz. (CARNELUTTI, 2002, p. 33)

Como sugestão para superação das concepções liberal e republicana (social), Habermas formula a proposta de paradigma procedimentalista, que, em síntese, representa um processo de autorregulação política da sociedade:

Daí as propostas mais relevantes desta teoria de democracia discursiva: (1) contra o privatismo burguês de um povo despolitizado e contra a redução legitimatória operada por partidos estatalizados é necessário regenerar a publicidade crítica através de formas deliberativas descentralizadas; (2) contra a compreensão da política centrada no estado

5 Chiovenda, sobre a possibilidade de a convicção de um juiz se basear em erro, dolo, provas insuficientes, acarretando em uma sentença decorrente de erro de fato ou de direito, admite que, juridicamente, a vontade concreta da lei é aquilo que o juiz afirmar ser a vontade concreta da lei. Contudo, defende que esses "defeitos inevitáveis no funcionamento prático do processo não podem influir sobre sua definição". Nesse sentido, afirma que "ninguém negará que a medicina seja a arte de curar as doenças só porque o erro do médico pode ser fatal ao enfermo" (CHIOVENDA, 2000, v.1, p. 64).

6 Sobre essa visão, afirmam Cintra, Grinover e Dinamarco (1993, p. 42): "O processo é, nesse quadro, um instrumento a serviço da paz social." 
procura-se dar vida a uma rede de comunicação e participação estruturante de uma sociedade democrática; (3) diferentemente da concepção ético-comunitarista republicana, a democracia discursiva parte das condições actuais de pluralismo cultural e social incompatíveis com uma identidade ético-comunitaria. (CANOTILHO, 1999, p. 1323)

Acompanhando o pensamento de Habermas, no paradigma procedimentalista, a constituição seria um "projeto aberto e permanente de construção de uma sociedade de cidadãos livres e iguais" (OLIVEIRA, 2006b, p. 87).

No âmbito da Teoria da Constituição, os reflexos da superação dos paradigmas jurídicos liberal e republicano (social) podem ser associados ao movimento neoconstitucionalista, que importou um repensar sobre a importância e o papel das constituições para os Estados.

O neoconstitucionalismo teve como marco histórico a promulgação da constituição da Itália de 1947 e da constituição da Alemanha de 1949, e a decorrente criação do Tribunal Constitucional Federal alemão em 1951 e da Corte Constitucional italiana em 1956 (BARROSO, 2009, pp. 245-246).

A proposta foi de colocar a constituição no centro do ordenamento jurídico, atribuindo-lhe força normativa e passando a considerá-la referente de construção e aplicação das normas infraconstitucionais. Nesse desiderato, houve uma necessidade de expansão da jurisdição constitucional, acarretando na criação de órgãos responsáveis pela aplicação e garantia da supremacia da constituição. A partir de então, o próprio legislador ordinário, em contraposição ao princípio da supremacia do parlamento, prevalente até então nos sistemas jurídicos romano-germânicos, ficou limitado ao texto constitucional (BARROSO, 2009, p. 264).

Essa limitação se deu com o avanço teórico a respeito dos direitos fundamentais que passaram a objeto de efetiva implementação, deixando de ser objeto de simples declaração (THEODORO JÚNIOR, 2009, p. 234). 
Outro fator importante decorrente do neoconstitucionalismo foi a estruturação das constituições a partir de princípios jurídicos. Estes superaram as funções meramente supletivas e interpretativas para se constituírem como espécie do gênero norma jurídica ao lado das regras jurídicas ${ }^{7}$.

Consolidado o Estado Democrático de Direito dentro dos avanços advindos com o neoconstitucionalismo e, principalmente, sustentado pelo paradigma procedimentalista habermasiano, a teoria do processo adequada não haveria de ser aquela iniciada por Bülow. ${ }^{8}$

A construção de uma teoria adequada ao Estado Democrático de Direito se torna possível, preliminarmente, com a adoção da teoria do processo como procedimento em contraditório de Fazzalari (2006). Partindo dos estudos desenvolvidos por esse autor, percebe-se que, em Ciência do Processo, não é a jurisdição o tema central, como pretende Dinamarco (2002, pp. 92-98), pois o processo deve ser o cerne dos estudos. Disso decorre a possibilidade de esclarecimento quanto à diferença existente entre processo e procedimento a partir do conceito de contraditório ${ }^{9}$. Nesse viés, o procedimento:

Sobre os princípios jurídicos como espécie do gênero norma, ver Alexy (1997).

8 Sobre a necessidade de superação da teoria do processo como relação jurídica, uma vez fundada no paradigma do Estado Social, Maciel Junior (2009, p. 309) afirma: "Tudo isso mudou no paradigma constitucional, mas ainda não chegou a ser efetivado. Continuamos apegados ao passado, reproduzindo um modelo anterior a 1988, como se tudo pertencesse a uma realidade imutável. Demonstramos falta de coragem para afirmar que nos livramos dos grilhões que nos amarravam a teorias fundadas no paradigma do Estado Social".

9 Dentro da teoria do processo como relação jurídica, não é possível ter uma diferenciação esclarecida de processo e procedimento. A diferenciação proposta nessa teoria se vincula à noção formal e teológica conforme a seguinte explicação: "O procedimento é, nesse quadro, apenas o meio extrínseco pelo qual se instaura, desenvolve-se e termina o processo; é a manifestação extrínseca deste, a sua realidade fenomenológica perceptível. A noção do processo é essencialmente teleológica, porque ele se caracteriza por sua finalidade de exercício do poder (no caso, jurisdicional). A noção de procedimento é puramente formal, não passando da coordenação de atos que se sucedem" (CINTRA; GRINOVER; DINAMARCO, 1993, p.235). Entretanto, considera-se insuficiente e pouco esclarecida a proposta acima, principalmente se verificados os conceitos de processo trazidos por Chiovenda e Carnelutti, que muito facilmente poderiam ser confundidos com o conceito de procedimento. Chiovenda se refere a processo da seguinte forma: "O processo civil é o complexo dos atos coordenados ao objetivo da atuação da vontade da lei (com respeito a um bem que se pretende garantido por ela), por parte dos órgãos da jurisdição ordinária" (CHIOVENDA, 2000, v. 1, p. 56). Já Carnelutti preconiza: "Chamamos (por antonomásia) processo a um conjunto de atos dirigidos a formação ou a aplicação dos preceitos jurídicos, cujo caráter consiste na colaboração para tal finalidade das pessoas interessadas" (CARNELUTTI, 2000, p. 72). 
[...] se verifica quando se está de frente a uma série de normas, cada uma das quais reguladora de uma determinada conduta (qualificando-a como lícita ou obrigatória), mas que enunciam como condição de sua incidência o cumprimento de uma atividade regulada por outra norma da série, e assim por diante, até a norma reguladora de um ato final. (FAZZALARI, 2006, p. 93)

E o processo:

Se, pois, o procedimento é regulado de modo que dele participem também aqueles em cuja esfera jurídica $o$ ato final é destinado a desenvolver efeitos - de modo que o autor dele (do ato final, ou seja, o juiz) deve dar a tais destinatários o conhecimento da sua atividade, e se tal participação é armada de modo que os contrapostos "interessados" (aqueles que aspiram à emanação do ato final - "interessados" em sentido estrito - e aqueles que queiram evitá-lo, ou seja, os "contra-interessados") estejam sob plano de simétrica paridade, então o procedimento compreende o "contraditório", faz-se mais articulado e complexo, e do genus "procedimento" é possível extrair a species "processo". (FAZZALARI, 2006, p. 94) ${ }^{10}$

Dentro na concepção fazzalariana, o procedimento se faz processo quando presente o contraditório, sendo este entendido como garantia de construção participada da decisão por aqueles que sofrerão os seus efeitos. Nesse intento, é possível verificar a justaposição da proposta fazzalariana com o paradigma procedimentalista (BARROS, 2009, p. 333).

Ainda no caminho da construção de uma teoria adequada ao Estado Democrático de Direito, é imprescindível apontar a aproximação do processo com a constituição, visto que os avanços teóricos conquistados

10 Interessante constatar que os conceitos de procedimento e processo apresentados não se limitam à atividade de aplicação do direito no âmbito jurisdicional. Fazzalari, tendo o processo como centro de sua pesquisa, inaugura a perspectiva da ciência do processo para os processos legislativo (2006, pp.705-710) e administrativo (2006, pp. 711-734). 
importaram na existência de um processo constitucionalizado como garantia da pessoa humana ${ }^{11}$.

No propósito de formulação teórica acerca desse tema, mostraramse pioneiros, na América Latina, Héctor Fix-Zamúdio (1974), Eduardo Couture (1948-1950) e José Alfredo de Oliveira Baracho (1984).

Baracho (2006, pp. 11-22 e 45-52), sistematizando uma teoria geral do processo constitucional, baseia-se, para formular a proposta de um modelo constitucional do processo, na supremacia das normas processuais da constituição sobre as normas processuais infraconstitucionais, no entendimento do processo como garantia constitucional e no direito das pessoas à atuação da jurisdição do Estado. O processo constitucional, partindo dos basilares identificados, funda-se: no direito de ação; no direito de ampla defesa; no direito ao advogado; no direito ao contraditório; no direito à produção de provas; no direito ao processo sem dilações indevidas; no direito a uma decisão proferida por órgão jurisdicional previamente definido no texto constitucional; no princípio da reserva legal; e no direito aos recursos.

Consolidando o pensamento acima, Andolina e Vignera (1997) propuseram a noção de modelo constitucional de processo embasado em três principais características: a expansividade, a variabilidade e a perfectibilidade. Flaviane Magalhães Barros, tratando sobre o tema, resume bem o que significa, para os citados autores, cada uma das três características:

[...] o modelo constitucional de processo é "um esquema geral de processo" que possui três importantes características: a expansividade, que garante a idoneidade para que a norma processual possa ser expandida para microssistemas, desde que mantenha conformidade com o esquema geral de processo; a variabilidade, como função de característica específica de um determinado microssistema,

11 Nesse sentido, José Alfredo de Oliveira Baracho preconiza como premissa acerca do processo constitucional: "a)A Constituição pressupõe a existência de um processo, como garantia da pessoa humana" (BARACHO, 1999, p. 89). Também afirma Andolina (1997, p. 64): "A Constituição traçou um verdadeiro modelo de processo jurisdicional, elevando o nível de garantias constitucionais em alguns pontos essenciais [...]". 
desde que em conformidade com a base constitucional; e, por fim, a perfectibilidade, como a capacidade do modelo constitucional se aperfeiçoar e definir novos institutos através do processo legislativo, mas sempre de acordo com o esquema geral. (BARROS, 2009, p. 334)

Analisando o texto constitucional brasileiro e tendo como ponto de partida todas as proposições apresentadas, pode-se avançar para além do conceito de processo formulado por Fazzalari. Trata-se de estabilizar a proposta fazzalariana e o modelo constitucional de processo com o paradigma procedimental no Estado Democrático de Direito.

O primeiro ponto a ser fixado é que, além do contraditório, apresenta-se, no texto constitucional, uma série de princípios correspondentes a direitos e garantias fundamentais relacionados ao processo, dentre os quais se pode destacar aqueles que o instituem. Dessa forma, o procedimento não se faz processo apenas com a presença do contraditório, mas com a presença desse e dos demais princípios institutivos correspondentes à ampla defesa e à isonomia (LEAL, 2010, p. 96).

Ademais, juntamente com os princípios institutivos, a CRFB/88 abarca como direitos procedimentais todos aqueles acima identificados, apresentados de forma sistematizada por Baracho (2006, pp. 11-22 e 45-52).

Diante dessas novas proposições, torna-se possibilitado o rompimento com o dogma do protagonismo das partes, vivenciado no paradigma liberal, e do protagonismo do juiz, vivenciado no paradigma social, para se pensar em um procedimento judicial que se estruture de forma a permitir que todos os sujeitos do processo participem da construção da decisão².

12 Nesse sentido: "A defesa 'atual' de que, para uma melhora do sistema jurídico, deve haver a procura de uma formação plural (humanística, jurídica, social e econômica) tão somente dos juízes, e não de todos os sujeitos processuais, parte do equívoco do protagonismo judicial que impede a compreensão da interdependência e do policentrismo processual, que imporia uma coparticipação e um reforço da importância e do papel de todos que se apresentam no processo" (NUNES, 2010, p. 104). 


\section{Urgência de tutela}

Cumpre destacar, preliminarmente, que se adota como correta a expressão intituladora do presente tópico, em detrimento da expressão "tutela de urgência", utilizada no texto do Projeto de Lei em análise. Justifica-se: a tutela está no conteúdo da lei, e o provimento jurisdicional nada mais faz do que aplicar esse conteúdo já previsto (MACIEL JUNIOR, 2006, pp. 161-185). Assim, não é possível atribuir a adjetivação "urgência" para o substantivo "tutela". Urgente há de ser a aplicação da tutela legal, o que explica a utilização terminológica "urgência de tutela"13.

Superada essa questão terminológica, é preciso delimitar qual problema envolve o estudo da urgência de tutela, como forma de se ter maior clareza na análise dos institutos inerentes.

Preocupa-se com a correta definição do problema por entender que grande parte dos estudos desenvolvidos sobre o tema, talvez por partirem de marcos teóricos superados, não conseguiram fazer essa definição. Por entenderem que o processo é instrumento da atuação da jurisdição, preconizam que os institutos da antecipação de tutela e tutela cautelar devam consistir em instrumentos à disposição dos juízes capazes de garantir a efetividade do processo (FUX, 1996, p. XII).

Não entenderam, porém, que não é o processo que deve ser efetivo. A efetividade visada deve ser a efetividade do direito, como bem já evidenciou o professor Fernando Horta Tavares (2007, pp. 111-118).

Para melhor compreensão da ideia acima, defende-se que a efetividade do direito pode advir por duas vias, a primeira mediante a observância dos destinatários das normas da licitude de suas condutas.

\footnotetext{
13 Vale ressaltar que terminologia utilizada não é de autoria dos elaboradores deste artigo. A referida expressão foi utilizada como título de obra coletiva organizada pelo professor Fernando Horta Tavares, intitulada Urgências de Tutelas - Processo Cautelar e Tutela Antecipada - Reflexões sobre a Efetividade do Processo no Estado Democrático de Direito. Essa terminologia já era utilizada pelo professor Rosemiro Pereira Leal, conforme afirmam Tavares, Assis, Mattos e Grande (2008).
} 
Diante da inobservância do destinatário, o acertamento do direito se dá através da instauração de procedimento judicial por aquele que se sinta prejudicado ou em risco de sê-lo pela ilicitude da conduta de outrem. Nessa hipótese, exige-se a efetividade dos procedimentos, como técnica prevista no Direito, com aptidão para acertar e satisfazer o direito pleiteado.

Para tanto, é necessário explicitar que um código de processo deve ser tratado como uma técnica, por conter um conjunto de procedimentos direcionados a um resultado útil: a aplicação do Direito na resolução de conflitos $^{14}$.

Como forma de se alcançar o resultado útil da técnica processual, teorizou-se, a partir da sistematização dos estudos de processo com Bülow, sobre a necessidade da existência de um procedimento apto a promover o acertamento do direito, denominado pelos estudiosos de processo de conhecimento; e de outro apto a promover a satisfação do direito, denominado de processo de execução ${ }^{15}$.

Nessa perspectiva, é possível entender que o procedimento judicial envolve uma série de atos reunidos em fases, como forma de permitir que os sujeitos processuais participem da construção do provimento de acertamento e satisfação. Todos esses atos e fases ocorrem dentro de lapsos temporais definidos na lei. Somando-se todos esses lapsos temporais, chega-se ao lapso temporal de todo o procedimento judicial.

Destacado o aspecto temporal do procedimento judicial, é lógico concluir pela impossibilidade de uma técnica de aplicação do Direito na resolução de conflitos que ocorra de forma instantânea, dentro das bases teóricas adotadas,

É nesse ponto que se encontra o problema relacionado ao estudo da urgência de tutela. Em determinadas situações, o lapso temporal

14 Apresenta-se a definição acima por entender que o objetivo principal da técnica processual é a aplicação do direito na resolução de conflito, não se esquecendo, por óbvio, das disposições referentes à jurisdição voluntária.

15 Dentro de uma concepção mais atualizada, o procedimento de conhecimento e o procedimento de execução constituem fases do procedimento judicial. Isso fica claro quando se analisam as alterações trazidas ao Código de Processo Civil pela Lei 11.232/2005. 
de duração do procedimento judicial se mostra prolongado, a ponto de inviabilizar o alcance de seu resultado útil, frustrando a satisfação do direito pleiteado ou impossibilitando a prática de algum ato futuro do procedimento. Por isso, como forma de solucionar o problema, foram teorizados o processo cautelar e a antecipação de tutela.

Apenas para propiciar um maior esclarecimento, vale destacar que o estudo das urgências de tutela, assim como o estudo da morosidade na prestação jurisdicional, está vinculado ao estudo da efetividade do direito. O fato de esses dois temas terem um tema mais amplo em comum tem levado ao equívoco de se trabalhar o processo cautelar e a antecipação de tutela como solução do problema da morosidade na prestação jurisdicional (FUX, 1996, p. 51).

Quanto a essa questão, é preciso entender que o problema da morosidade encontra solução na observância, pelo Estado, do princípio da eficiência ${ }^{16}$. Espera-se que sejam revistas as práticas administrativas do órgão jurisdicional e sua forma de atuação, como sujeito do processo, no procedimento judicial. Já o problema que a antecipação de tutela e o processo cautelar se prestam a resolver continua a existir, mesmo solucionado o problema da morosidade, exigindo que sejam pensados de forma separada ${ }^{17}$.

16 Também nesse sentido defende o professor Brêtas (2010. pp. 141-146). Aqui, vale destacar que o problema da morosidade na prestação jurisdicional apenas pode ser atribuído à atuação do órgão jurisdicional, visto que os demais sujeitos atuam no procedimento observando os prazos legais estipulados, sob pena de preclusão. Por isso, adere-se à proposição da observância do princípio da eficiência como fator de afastamento do problema da morosidade na prestação jurisdicional.

17 Sobre esse ponto, vale menção a Zavascki, que, desenvolvendo estudos sobre a tutela provisória para relacioná-la aos institutos da cautelar e antecipação de tutela, destaca: "Todavia, como é fácil de perceber, a prestação da tutela definitiva não é instantânea. Entre o pedido e a entrega efetiva - período durante o qual se exercerão contraditório e ampla defesa - decorrerá, necessariamente, um razoável espaço de tempo, por mais sumário que seja o rito procedimental e por mais eficientes que sejam os serviços judiciários" (ZAVASCKI, 1997. p. 25). Também Ovídio Baptista, ressalvado o aspecto instrumentalista do autor, atento aos problemas da má utilização do instituto da cautelar, diz: "Os que, com certa ingenuidade, veem no processo cautelar esse sonhado mecanismo milagroso, em virtude do qual as partes poderiam obter uma justiça rápida e eficiente, esquecem que o juiz, infelizmente, não pode oferecer qualquer vantagem processual a um dos litigantes senão à custa do outro; e que a liminar não surge espontaneamente do nada, como um fenômeno de geração espontânea, sendo, ao contrário, determinada mediante a imposição de um correspondente sacrifício processual, como dissera Calamandrei (II Processo come Giuoco, Opere Giuridiche, I, 553)" (SILVA, 2001. p. 7). 


\subsection{Processo cautelar}

Diante da limitação da técnica de aplicação do Direito quanto ao seu aspecto temporal, houve a necessidade de teorização de institutos capazes de superar os problemas relacionados à necessidade de urgência na aplicação da tutela legal.

A primeira proposta, concebida pelos processualistas italianos, foi a teorização de um terceiro gênero de procedimento que restou, denominado processo cautelar, em complementação aos já teorizados processo de conhecimento e processo de execução (SILVA, 2001, p. 3).

De índole eminentemente declarativa e pautado pelo princípio dispositivo (SILVA, 2001, p. 3), o processo cautelar visa solucionar o problema da urgência de aplicação da tutela legal no que tange à garantia do resultado útil da técnica de aplicação do Direito na resolução de conflitos, resguardando-se a possibilidade de prática de ato ou fase futura de procedimento já instaurado ou a instaurar.

Com base na legislação vigente, quando um requerente instaura um procedimento cautelar específico de arresto, por exemplo, seu intuito é alcançar uma medida acautelatória que assegure o não perecimento de coisas diante de um risco, garantindo a possibilidade de prática do ato de expropriação na fase satisfativa. Da mesma forma, quando um requerente instaura um procedimento cautelar específico de produção antecipada de provas, seu intuito é alcançar uma medida acautelatória que assegure o não perecimento de provas diante de um risco, garantindo a possibilidade de realização da fase probatória mediante a antecipação de práticas de atos inerentes a essa fase. Por fim, com a instauração de um procedimento cautelar específico de busca e apreensão de menores, o requerente busca uma medida acautelatória que assegure o não perecimento de pessoas diante de um risco, garantindo a possibilidade de realização de ato executivo, definida a guarda em um procedimento de divórcio, por exemplo.

Por isso, fala-se que a instauração de um procedimento cautelar visa assegurar o não perecimento de provas, pessoas e coisas enquanto 
perdure uma situação cautelanda (risco de perecimento), em que a não concessão de medida cautelar poderia acarretar em dano irreparável ou de difícil reparação (periculum in mora). Nos procedimentos cautelares, formula-se haver uma cognição sumária apta à construção de uma plausibilidade do direito (fumus boni iuris) como razão de decisão para o provimento mandamental de caráter temporário a ser prolatado.

Necessário romper, como assim fez Ovídio Baptista (SILVA, 2001, pp. 34-41), com o equívoco doutrinário em definir o procedimento cautelar como instrumento assessório do procedimento principal (FUX, 1996, p. 20). Quando se defende que o processo cautelar visa assegurar a prática ou participação em fase de um procedimento cognitivo e executivo, deve-se entender que o instituto tem finalidade própria. Atender seu fim independe da instauração de outro procedimento dito principal ou do resultado final alcançado neste.

Esclarecido esse ponto da autonomia do processo cautelar, é possível explicitar que a plausibilidade do direito (fumus boni iuris) como pressuposto para concessão de uma medida cautelar não está num possível resultado favorável ao requerente no procedimento dito principal; está na afirmação do requerente da medida cautelar que tem direito de assegurar, diante de uma situação cautelanda, a possibilidade de prática de ato ou participação em fase de um procedimento judicial, instaurado ou a instaurar, de acertamento e satisfação de direito.

Também nesse sentido, o pressuposto do dano irreparável ou de difícil reparação não se vincula ao objeto mediato do procedimento dito principal, fundando argumentação na impossibilidade de satisfação do direito pleiteado diante da não concessão da medida cautelar. Quando se pretende o perigo de dano irreparável ou de difícil reparação (periculum in mora) como pressuposto para concessão da medida cautelar, querse que o requerente demonstre não ser possível aguardar os lapsos temporais estabelecidos em lei para prática de ato ou realização de fase do procedimento judicial sem que haja perecimento de pessoas, provas ou coisas imprescindíveis à prática do ato ou à realização da fase.

O Código de Processo Civil vigente dedica o livro III para as previsões pertinentes ao processo cautelar, estabelecendo os 
procedimentos cautelares específicos e prevendo, no artigo 798, o poder geral de cautela, pelo qual fica o magistrado autorizado a determinar medidas acauteladoras quando houver fundado receio de uma parte, antes do provimento jurisdicional, causar a outra parte dano grave e de difícil reparação.

Visualiza-se, no poder geral de cautela, cláusula aberta a permitir a atuação discricionária do magistrado quando se admite que este tome as medidas que entender necessárias. Defende-se que não existe espaço, dentro de uma proposta de Estado Democrático de Direito, para atuação discricionária do magistrado, a qual deve ser vinculada, como bem formulou Lênio Streck (2009, pp. 3-27).

Pela permissão da atuação discricionária do magistrado, amparada pelo poder geral de cautela, o instituto da cautelar passou a ser utilizado de forma desvirtuada para solucionar um problema distinto daquele que levou à sua formulação. Buscava-se, antes da previsão legal do instituto da antecipação de tutela, utilizando-se do poder geral de cautela, a concessão de medidas antecipatórias pela "ação cautelar satisfativa" (MARIONI, 1997, pp. 81-85).

Apesar de o processo cautelar e de a antecipação da tutela estarem vinculados ao problema da urgência de tutela, cada qual dos institutos visa solucionar um problema específico. A compreensão da distinção entre os institutos e a correta definição dos problemas que cada um pretende solucionar são ganhos teóricos relevantes, consistindo em atraso defender fungibilidade entre um e outro. Por isso, dedicar-se-á o próximo tópico ao estudo da antecipação de tutela, pontuando suas diferenças com o instituto ora estudado.

\subsection{Antecipação de tutela}

Dentro da proposta desenvolvida no tópico anterior, preconiza-se que a antecipação de tutela é um instituto de Direito Processual teorizado para solucionar o seguinte problema: existem situações em que o lapso temporal entre a instauração do procedimento e o provimento final, por 
se mostrar demais alongado, pode acarretar em dano irreparável ou de difícil reparação para a parte requerente, por frustrar a possibilidade de satisfação do direito pleiteado.

De um lado, o processo cautelar visa garantir o resultado útil da técnica processual mediante o asseguramento de pessoas, provas e coisas imprescindíveis à prática de ato ou fase do procedimento. Por outro, o instituto da antecipação da tutela visa antecipar os efeitos do resultado útil da técnica processual, aplicando o direito na resolução de conflitos. Nesse caso, alcança-se o direito alegado, em caráter provisório, mediante uma cognição sumária, embasada nos pressupostos da verossimilhança das alegações, prova inequívoca e risco de dano irreparável ou de difícil reparação.

A legislação brasileira ${ }^{18}$, com fulcro na doutrina (MARINONI, 1997, pp. 75-79), considera que a prática de atos protelatórios pelo requerido é pressuposto alternativo em relação ao risco de dano irreparável ou de difícil reparação. Ou seja, mesmo que não exista risco de dano irreparável ou de difícil reparação, constatada a atuação protelatória do requerido e presentes os pressupostos da verossimilhança e prova inequívoca, haveria razão para concessão de medida antecipatória ${ }^{19}$.

Nesse ponto, visualiza-se o maior equívoco relacionado ao instituto da antecipação de tutela. Como visto acima, esse instituto foi teorizado para solucionar um problema relacionado à urgência de tutela, suprindo a limitação do procedimento judicial quanto ao seu aspecto temporal. Se não existe risco de dano irreparável ou de difícil reparação vinculado à temporariedade procedimental, não há que se falar em concessão de medida antecipatória. Defender a atuação protelatória do requerido

\footnotetext{
18 Inciso II, artigo 273 do Código de Processo Civil (BRASIL, 1973).

19 Ainda sobre a antecipação da tutela, vale ressaltar a previsão, no parágrafo sexto do artigo 273 do Código de Processo Civil vigente, da possibilidade de concessão de medida satisfativa quando o pedido ou parte dele se mostrar incontroverso. Tratar-se-á sobre o tema quando da análise da tutela de evidência, no tópico 4.1.
} 
como pressuposto alternativo para concessão de medida antecipatória é desvirtuar um instituto, desvinculando-o da barreira que se presta a resolver. É ainda romper com a ordinariedade do procedimento judicial de forma desnecessária, buscando solucionar o problema da morosidade na prestação jurisdicional com um instituto que não se oferece a isso.

É preciso entender que a demora ocasionada por uma atuação protelatória do requerido decorrente de má-fé já encontra solução prevista no Código de Processo Civil vigente, do artigo 16 ao artigo 18. Assim, se, por ventura, ficar constatada a má-fé do requerido ou requerente, a solução não é a antecipação da tutela, e sim a aplicação dos citados artigos.

Considerando a proposta de releitura dos pressupostos para concessão da medida cautelar, conclui-se não existir correspondência entre o fumus boni iuris e a verossimilhança das alegações. Como dito no tópico anterior, o pressuposto para concessão da medida cautelar corresponde ao direito do requerente de ter assegurada pessoa, prova ou coisa imprescindível à pratica de ato ou fase de um procedimento de acertamento ou satisfação. Defende-se não haver qualquer análise de plausibilidade do direito alegado no procedimento cognitivo e satisfativo. Em sentido contrário, quando se estuda a verossimilhança das alegações como pressuposto para concessão de uma medida antecipatória, por se estar diante de antecipação do resultado útil da técnica processual, mesmo que em caráter provisório, há, sim, análise da plausibilidade do direito alegado no procedimento judicial de acertamento e satisfação.

Quanto ao pressuposto da prova inequívoca, crível se pensar que sua análise encontra íntima ligação com o pressuposto da verossimilhança. Isso porque, para se alcançar uma plausibilidade do direito, é importante que as alegações formuladas encontrem demonstração em elementos objetivos da realidade, alcançados pelos meios admitidos na lei e dispostos nos autos pelos respectivos instrumentos. Necessário se pensar que não existe prova inequívoca antes de seu oferecimento ao contraditório, visto que a inequivocidade se alcança não só pela convicção do magistrado, mas pela discursividade 
oportunizada aos sujeitos do processo na valoração e valorização da prova $^{20}$.

Ainda dentro dessa perspectiva, orientando-se pelos avanços teóricos tratados no tópico 2, defende-se ser inapropriada a possibilidade de concessão de medida antecipatória inaudita altera parte. Afirmase isso por entender que o exercício do direito fundamental de contraditório ${ }^{21}$ abrange uma série de conquistas teóricas inafastáveis na contemporaneidade. O contraditório abarca a possibilidade de participação daqueles que sofrerão os efeitos da decisão, estando em consonância com a proposta habermasiana de legitimidade (HABERMAS, 1997). Ele contém a conquista teórica da Filosofia da Linguagem, considerando que a construção do conhecimento (decisão) se dá pela relação linguagem-mundo (processo-sujeitos), e não pela relação sujeito-objeto (juiz-conflito). O contraditório absorve, ainda, a conquista teórica da teoria do conhecimento de Popper (1999), visto a possibilidade de construção de verdades (provisórias) mediante testificações e refutações ${ }^{22}$.

Por isso, defende-se que futuros trabalhos acadêmicos, em vez de buscarem justificativas para a possibilidade de ausência de contraditório ou contraditório postergado, deveriam pensar em formas de se operacionalizar o contraditório em casos de urgência, avaliando a hipótese de adequação do prazo de resposta à necessidade temporal do caso concreto. Veja que a busca de operacionalização se dá no âmbito do aperfeiçoamento da técnica, sem a necessidade de discussão teórica quanto à imprescindibilidade do contraditório como pressuposto para decisões. Com isso, muda-se o foco do problema do âmbito da

\footnotetext{
20 Sobre o instituto da prova estudado dentro da proposta de um Estado Democrático de Direito, ver parte da obra de Rosemiro Pereira Leal (2010, pp. 207-216).

21 Sobre o princípio do contraditório visto sob a ótica aqui tratada, ver artigo de Dierle José Coelho Nunes (2008. pp.145-165).

22 Como dito, todos esses avanços foram tratados no tópico 2, com o fim de demonstrar ao leitor qual o caminho percorrido para o alcance das críticas e propostas apresentadas. Assim, para melhor compreensão do trecho acima, recomenda-se a leitura do tópico.
} 
Ciência do Direito para um âmbito que pode contar com o auxílio de outras ciências, como a Administração, Informática e Engenharia de Automação, possibilitando aos procedimentos judiciais a presença irrestrita do contraditório ${ }^{23}$.

\section{Tutela de urgência e tutela de evidência no projeto do novo Código de Processo Civil}

Como resultado das discussões travadas pela comissão de juristas responsável pela elaboração de novo Código de Processo Civil, foram inseridos os institutos das tutelas de urgência e de evidência na parte geral do Código, ou seja, no título IX do livro I, unificando o instituto da cautelar e da antecipação de tutela, antes previstos, respectivamente, no livro III (entre os artigos 796 a 889) e artigo 273 do Código de Processo Civil de 1973.

Entre os artigos 277 e 282 do projeto do novo Código de Processo Civil, há as disposições comuns das tutelas de urgência e de evidência, restando, do artigo 286 ao artigo 293, a previsão do procedimento.

A teorização da tutela de evidência é toda desenvolvida em torno do instituto da antecipação da tutela. De forma desvirtuada, buscou-se desenvolver uma hipótese sem estar presente o principal pressuposto para sua formulação, que é o dano de risco irreparável ou de difícil reparação relacionado ao aspecto temporal do procedimento.

A expressão "tutela de evidência" não é nova no Projeto de Lei em análise. Luiz Fux, presidente da comissão de juristas do novo Código de Processo Civil, utiliza-se dela e a vincula "àquelas pretensões deduzidas em juízo nas quais o direito da parte revela-se evidente, tal como o direito líquido e certo que autoriza a concessão do mandamus

23 Sabe-se que a ideia desenvolvida no presente parágrafo exige trabalho mais aprofundado, pontuando com maior precisão os motivos da impossibilidade de contraditório postergado. Entretanto, esse não é o objetivo principal do presente artigo. 
ou o direito documentado dos exequentes" (FUX, 1996, p. 305). Sob o ângulo do Direito Civil e Direito Processual, o direito evidente, nos dizeres de Luiz Fux, é "[...] aquele que se projeta no âmbito do sujeito de direito que postula. Sob o prisma processual, é evidente o direito cuja prova dos fatos sobre os quais incide revela-se incontestável ou ao menos impassível de contestação séria" (FUX, 1996, p. 311).

Merece consideração a previsão do artigo 277, que faz supor existir hipótese de tutela de evidência de natureza cautelar. Ora, analisando-se os incisos do artigo 285, fica claro estarem presentes apenas hipóteses em que se adiantarão os efeitos da tutela legal, ou seja, alcançar-se-á medida de caráter satisfativo.

Como visto acima, o instituto da antecipação de tutela foi teorizado para resolver a limitação da técnica processual quanto a um aspecto de temporalidade procedimental. Ou seja, rompe-se a ordinariedade do procedimento para atender a uma necessidade de urgência. Quando se desenvolve a proposta de tutela de evidência a partir do instituto da antecipação de tutela, vê-se um equívoco tremendo ao tentar se resolver o problema da morosidade da prestação jurisdicional à custa de direitos fundamentais do cidadão, e não à custa de um Estado mais eficiente ${ }^{24}$.

Para concessão de medida embasada em tutela de evidência, conforme previsão no Projeto de Lei em análise, não se exige o pressuposto do risco de dano irreparável ou de difícil reparação caso: haja abuso do direito de defesa ou manifesto propósito protelatório do requerido; um ou mais dos pedidos cumulados, ou parcela deles, mostre-se incontroverso; a inicial seja instruída com prova documental irrefutável do direito alegado pelo autor, a que o réu não oponha prova inequívoca ou a matéria seja unicamente de direito; haja jurisprudência firmada em julgamento de casos repetitivos ou súmula vinculante.

24 Conforme tratado no tópico 3, mesmo num Estado em que o órgão jurisdicional seja o mais eficiente possível, sempre haverá, enquanto a teoria do processo conduzir a técnica processual de resolução de conflitos, necessidade das tutelas de urgência. Por isso se defende que a morosidade se resolve com eficiência do órgão jurisdicional, e a limitação do aspecto temporal do procedimento judicial se resolve com processo cautelar e antecipação de tutela. 
Sobre os pressupostos alternativos ao risco irreparável ou de difícil reparação, para caracterização de hipótese de tutela de evidência, algumas observações são mais que necessárias.

Assim, a proposta do novo Código, repetindo a previsão existente no Código vigente, coloca o "abuso de direito de defesa ou o manifesto propósito protelatório do requerido" como ensejador de rompimento com a ordinariedade do procedimento. Ora, é notório que toda defesa é exercida dentro dos prazos legais previstos, os quais, aliás, são exíguos, correspondendo, em média, a dez dias. Claro, também, que o exercício do direito de defesa dentro dos prazos legais decorre do direito fundamental de ampla defesa. Nesse sentido, é necessário romper com a ideia equivocada de que o exercício do direito de defesa é empecilho para a prestação jurisdicional célere, pois protelatória é a atuação do Estado, que pratica seus atos fora dos prazos estabelecidos na lei.

No caso em que há antecipação da parte incontroversa da demanda, vê-se um dispositivo desnecessário. Ora, se a parte adversa reconhece parte do pedido do requerente pela simples observância do princípio da boa-fé processual, haver-se-ia de adiantar os efeitos da tutela legal. Assim, bastaria conter a previsão de que a parte incontroversa da demanda seria, desde já, adiantada, sem vinculá-la ao instituto da tutela antecipada, o qual, como já visto, presta-se às urgências.

No caso em que a "matéria for unicamente de direito e houver jurisprudência firmada em julgamento de casos repetitivos ou súmula vinculante", questiona-se como vêm sendo construídos os julgamentos repetitivos e as súmulas. Nota-se que grande parte desses julgados é construída sem qualquer legitimidade democrática, constituindose em decisões autoritárias tomada pelos tribunais, sem o devido amadurecimento da matéria e sem a participação daqueles que sofrerão os efeitos, em grave violação à garantia constitucional do contraditório ${ }^{25}$. Nos dizeres de Aroldo Plínio Gonçalves:

25 Para melhor compreensão do parágrafo, remete-se o leitor ao tópico 2. Nessa parte do texto, desenvolveu-se um esforço teórico embasador da afirmação ora formulada. 
O contraditório é a garantia de participação, em simétrica paridade, das partes, daqueles a quem se destinam os efeitos da sentença, daqueles que são os "interessados", ou seja, aqueles sujeitos do processo que suportarão os efeitos do provimento e da medida jurisdicional que ele vier a impor. (GONÇALVES, 1992, p. 120)

Dierle José Coelho Nunes esclarece que:

Não se pode acreditar mais em uma justiça social predefinida antes do debate processual, eis que só as peculiaridades do caso concreto (não de uma massa de casos), definidas endoprocessualmente, conseguem permitir, mediante o estabelecimento de um fluxo discursivo entre os interessados e o órgão decisor, a formação de um provimento adequado.

Em sociedades pluralistas e, ao mesmo tempo, globalizadas, não existem referenciais estanques e predeterminados que poderão ser seguidos e descobertos por qualquer um, seja uma instituição de controle central (v.g., Estado e Igreja), órgão ou pessoa (v.g, presidente, führer ou juiz). (NUNES, 2009, p. 356)

Traçadas as necessárias críticas ao instituto da tutela de evidência, segue-se na análise mais técnica das preposições referentes aos institutos no novo Código.

O parágrafo único do artigo 279 do projeto do novo Código de Processo Civil prevê que a decisão que concede ou nega a tutela de urgência ou evidência é impugnável através de agravo de instrumento. Nota-se, portanto, que tal decisão tem natureza interlocutória. Quanto à impugnação de decisão que concede ou nega tutela de urgência, fica claro, exatamente pela suposta existência de risco de dano irreparável ou de difícil reparação, que o agravo de instrumento seria o meio de impugnação mais apropriado. Entretanto, quando se fala da impugnação de decisão que concede ou nega a tutela de evidência, não se percebe a urgência necessária para desafiar a interposição de agravo de instrumento. Como o projeto de lei extingue o agravo retido, talvez o 
mais apropriado seria atacar a decisão interlocutória em questão no momento de impugnação da sentença de mérito. Sobre a extinção do agravo retido:

Em matéria recursal, o recurso de agravo será extinto, não havendo preclusão no curso do processo, salvo para as questões urgentes e para as cautelares. Haverá o estabelecimento de um único recurso de apelação no qual a parte manifestará todas as suas irresignações quanto às decisões interlocutórias proferidas no curso do processo. (SOARES, 2010, p. 120)

Discussão interessante gira em torno da classificação da decisão que concede a tutela de urgência e não há impugnação da parte contrária, acarretando na sua efetivação integral (estabilização da tutela). Nas audiências públicas, houve diversas discussões sobre o tema. Tereza Arruda Alvim Wambier defendeu se tratar de sentença de mérito; José Roberto dos Santos Bedaque preconizou ser decisão interlocutória; Luiz Fux inovou ao dizer se tratar de interlocutória de mérito ${ }^{26}$.

Não foram previstos, no novo Código de Processo Civil, os procedimentos cautelares específicos, o que se faz concluir pelo rompimento com o Código de 1973 (de autos apartados para o procedimento cautelar). Quanto ao requerimento de antecipação de tutela, ele já era formulado e se desenvolvia nos autos do procedimento dito principal.

O novo Código traz inovação ao transferir as previsões do instituto da cautelar acerca do asseguramento de provas para o título das provas, demonstrando certa sistematização ao pretender uma reunião dos dispositivos referentes à produção probatória ordinária ou em sede cautelar. Destarte, os procedimentos cautelares de exibição, produção antecipada de provas, arrolamento de bens com a finalidade de realização de documentos e a justificação, previstos no livro III do Código vigente, no Projeto de Lei, foram transferidos para o título VII.

\footnotetext{
26 Ata da $11^{\text {a }}$ Reunião, realizada em 23 de abril de 2010.
} 
Com a extinção dos procedimentos cautelares específicos, a comissão pretendeu deixar apenas um procedimento apto para a construção de um provimento (medida) de caráter cautelar e de caráter satisfativo. Não bastasse os equívocos oriundos da proposta acima, a comissão também buscou unificar os pressupostos para a concessão da medida assecuratória e satisfativa, incorrendo em erro já constatado por Humberto Theodoro Júnior:

O art. 283 arrola para a tutela cautelar (conservativa) e a tutela antecipatória (satisfativa) os mesmos requisitos, sem atentar para a diversidade de consequências práticas e jurídicas que advém de uma medida neutra, como é a conservativa, e de uma medida de mérito, como é a de antecipação de tutela substancial. Questões como a da inequivocidade da prova e da reversibilidade da medida, data venia, não deveriam ser desprezadas quando se trata de antecipação dos efeitos da futura sentença de mérito. A experiência do atual Código, em seu art. 273, não deveria ter sido desprezada. As duas situações são substancialmente heterogêneas, de modo a não permitir tratamento processual homogêneo. (THEODORO JÚNIOR, 2010, p. 8)

No mais, sem procedimentos cautelares específicos que estabeleçam um parâmetro objetivo ao julgador, preconiza-se a possibilidade de se aumentar a atuação discricionária do magistrado. Isso porque, como já anotado em tópico anterior, mesmo com previsões de procedimentos cautelares específicos, que seriam aptos a objetivar a atuação do magistrado, viu-se a utilização do poder geral de cautela para concessão de medida satisfativa antes da previsão legal do instituto da antecipação de tutela. Nesse sentido, defende-se que a existência de poderes discricionários, ainda mais para concessão de provimentos construídos por uma atividade de cognição sumária, é questionável em um Estado Democrático de Direito. Toda decisão judicial, como já defendido, deve ser vinculada, sendo observado o princípio da legalidade na atuação do órgão jurisdicional. 
Nos dizeres de Ronaldo Brêtas de Carvalho Dias:

Assim, os órgãos jurisdicionais, ao proferirem suas decisões, cumprindo e finalizando a função jurisdicional, deverão fazê-lo direcionados pelo princípio da vinculação ao Estado Democrático de Direito. Este princípio se otimizará pela incidência articulada de dois outros princípios, ou subprincípios concretizadores (Larenz), no ato estatal de julgar. Nessa ótica, os princípios concretizadores daquele princípio maior vêm a ser o princípio da supremacia da Constituição e o princípio da reserva legal (ou princípio da prevalência da lei). (BRÊTAS, 2004, p. 132)

O artigo 277 do projeto do novo Código de Processo Civil prevê que a tutela de urgência e a tutela de evidência podem ser requeridas antes ou no curso do procedimento, sejam essas medidas de natureza cautelar ou satisfativa. Aqui, percebe-se a despreocupação da comissão em estabelecer diferença entre ambas. Talvez por isso a previsão de fungibilidade entre elas. Percebe-se, ainda, a manutenção da possibilidade de requerimento de medidas preparatórias, algo que terá importância ao se tratar da estabilização da tutela.

Como já exposto nos itens acima, o instituto da cautelar busca garantir proteção a pessoas, bens ou coisas que estão em estado de perigo. Já a antecipação da tutela visa à aplicação antecipada da lei (não à antecipação da sentença), também diante de um caso de urgência. Entretanto, a situação de urgência, como já defendido acima, não tem o condão de afastar o devido processo constitucional, sendo descabida a previsão do parágrafo único do artigo 283 do Projeto de Lei. Por isso, não há que se falar em possibilidade de concessão de medida liminar. Qualquer decisão que se pretenda dentro de parâmetros democráticos exige a audiência da parte contrária para que participe da construção da decisão que irá afetá-la.

Em seguida, no artigo 278 do Projeto, está prevista a possibilidade de o juiz determinar as medidas que considerar adequadas quando houver receio de que uma parte, antes do julgamento da lide, cause ao direito da outra parte lesão grave ou de difícil reparação. Aqui, 
visualiza-se a previsão que possibilita ao magistrado de ofício conceder medidas assecuratórias ou satisfativas, presentes os pressupostos para concessão da tutela de urgência. Observa-se que o juiz poderá determinar as medidas que "achar" adequadas, não havendo qualquer limitação de sua atuação na lei, constituindo poder discricionário do julgador. Se a medida, além de concedida por ofício for concedida liminarmente, perceber-se-á uma afronta aos artigos $1^{\circ}$ e 10 do Projeto:

Art. $1^{\circ}$ O processo civil será ordenado, disciplinado e interpretado conforme valores e os princípios fundamentais estabelecidos na Constituição da República Federativa do Brasil, observando-se as disposições deste Código.

\section{$[\ldots]$}

Art.10. O juiz não pode decidir, em grau algum de jurisdição, com base em fundamento a respeito do qual não se tenha dado às partes oportunidades de se manifestar, ainda que se trate de matéria sobre a qual tenha que decidir de ofício. (COSTA, 2010).

Além do conflito do artigo 278 com os artigos $1^{\circ}$ e 10 acima mencionados, há conflito daquele artigo com o texto constitucional. No Estado Democrático de Direito, há a participação argumentativa das partes na construção da decisão judicial, não sendo esta um ato de surpresa para as partes. No mais, o que se busca é a efetividade do direito, sempre observando o devido processo constitucional, e não decisões rápidas para resolver o problema estrutural/burocráticos da função jurisdicional ${ }^{27}$.

Ressalta-se o entendimento de Dhenis Cruz Madeira:

No entanto, sabe-se que o aparelho judiciário deve ser eficiente eque a efetividade deve ser alcançada. Obviamente,

27 Pontuado o já tratado nas notas citadas, defende-se que, constatado um prejuízo de uma parte pela morosidade na prestação jurisdicional, ela deve buscar reparação civil de seus danos em relação àquele que os casou, ou seja, o Estado. Destarte, não é em prejuízo da parte contrária que se deve solucionar o problema da morosidade na prestação jurisdicional. Diante de um Estado ineficiente, este deve ser responsabilizado por seus atos ou omissões causadores de danos (BRÊTAS, 2004). 
tal eficiência e busca da efetividade não podem se dar com a quebra da legitimidade decisória e, muito menos, com a supressão do devido processo, dos princípios institutivos e dos direitos fundamentais. A efetividade, acima de tudo, é da lei, não se admitindo decisões meramente ágeis, vigorosas e truculentas.

Assim, de um lado, tem-se a busca da efetividade, da eficiência; de outro, o paradigma constitucional do Estado Democrático de Direito, que rejeita a decisão solipsista, ainda que para atendimento da celeridade, economia processual e outros importantes princípios informativos. Certamente, entre confronto entre normas constitucionais e infraconstitucionais, a última é alijada. (MADEIRA, 2007, p. 70)

\subsection{Estabilização da tutela}

Não há mais a necessidade de se apresentar o pedido principal para manter a efetivação da medida requerida em caráter antecedente, contemplando o novo Código de Processo Civil brasileiro a estabilização da tutela antecipada, inspirando-se no Direito italiano e no Direito francês, conforme previsão expressa na exposição de motivos do Projeto de Lei.

A estabilização da tutela não é prevista no Código de Processo Civil de 1973, embora houvesse o Projeto de Lei $\mathrm{n}^{\circ} 186$, de 2005 , no Senado Federal, com o objetivo em modificar os $\$ \S 4^{\circ}$ e $5^{\circ}$ do artigo 273 e acrescentar os artigos 273-A, 273-B, 273-C e 273-D para permitir a estabilização da tutela.

A estabilização da tutela no novo Código de Processo Civil tem o objetivo de conservar a eficácia da medida requerida em caráter antecedente até que seja impugnada pela parte contrária, mediante a instauração de outro procedimento. Ocorre quando um indivíduo instaura procedimento pretendendo que seja concedida medida cautelar ou satisfativa em caráter antecedente e o magistrado conceda a medida liminarmente. Diante da ausência de impugnação da medida liminar por parte do requerido, o juiz extinguirá o procedimento, conservando a eficácia da medida. Os efeitos da medida apenas cessarão se o outrora 
requerido instaurar procedimento com o intuito de discutir o direito acautelado ou os efeitos que tenham sidos antecipados. Nesse caso, os efeitos persistirão até a decisão final desse procedimento, visto a impossibilidade de se requerer, neste, medida de urgência.

$\mathrm{Na}$ exposição de motivos e no artigo 293 do novo Código de Processo Civil, há previsão expressa de que a medida liminar não impugnada pela parte contrária não seja protegida pela coisa julgada: "Não tendo havido resistência à liminar concedida, o juiz, depois da efetivação da medida, extinguirá o processo, conservando-se a eficácia da medida concedida, sem que a situação fique protegida pela coisa julgada" (COSTA, 2010).

Embora a medida não faça coisa julgada, não há segurança jurídica para as partes se tal medida puder ser impugnada a qualquer tempo. Como não há previsão no novo Código de Processo Civil de um prazo para se questionar a medida, noutro procedimento, o prazo para se insurgir contra a decisão serão os prescricionais e decadenciais previstos no Código Civil.

Somente no caso de impugnação da medida cautelar ou antecipatória o pedido principal deverá ser apresentado no prazo de um mês ou em outro prazo que o juiz fixar (outra inovação no novo projeto do Código de Processo Civil), mas a parte deverá requerer e demonstrar o motivo da necessidade de prazo diverso em lei, não podendo o magistrado agir de ofício.

O pedido principal deverá ser apresentado nos mesmos autos que houver veiculado o requerimento da medida de urgência ou evidência, não dependendo de pagamento de custas processuais. Tal medida demonstra um dos objetivos do novo Código, exposto na exposição de motivos: "um processo civil mais célere".

\subsection{Direito Comparado}

A tutela de urgência e a tutela de evidência, no novo Código de Processo Civil, foram inspiradas no Direito italiano e no Direito francês, 
assim como o processo cautelar e a antecipação de tutela do Código de Processo Civil de 1973.

O Direito italiano divide provimento de urgência e provimento cautelar no livro IV do Código de Processo. A doutrina italiana, como salienta Luiz Fux:

[...] entrevê noutros dispositivos esparsos e especiais medidas cautelares não enumeradas como tal pelo Código. A utilização desse poder cautelar genérico pressupõe a inexistência de medida típica e processo de conhecimento, em face da expressão 'via ordinária', utilizada no art. 700 . (FUX, 1996. p. 172)

Assim, no Direito Processual italiano, a antecipação de tutela é limitada quando não há medida típica prevista, conforme determina o artigo 700 do Código de Processo da Itália (ASSIS, 2007, p. 183), assumindo caráter subsidiário e aplicada somente quando não há previsão para os procedimentos cautelares. Zamira de Assis destaca que

A previsão da medida assume um caráter subsidiário ao estatuir que somente fora dos casos regulados nas seções precedentes do Capítulo III (que trata dos procedimentos cautelares), se houver fundado motivo para temer que durante o tempo ocorrente para fazer valer seu direito na via ordinária este seja ameaçado de um prejuízo iminente e irreparável, poderá ajuizar pedido judicial de urgência que, aparelhado segundo a circunstância, seja idôneo a assegurar provisoriamente os efeitos da decisão de mérito. O conteúdo dessa medida define-se de acordo com o caso concreto, já que não há predeterminação legislativa, podendo coincidir com os efeitos que seriam obtidos na futura decisão de mérito, cuja antecipação objetiva neutralizar os efeitos de um prejuízo iminente e irreparável. (ASSIS, 2007, pp. 183-184)

Já no Direito francês, há a previsão de medidas provisórias e conservatórias, como os artigos 808 a 811 do Código de Processo Civil francês. A doutrina francesa ainda prevê uma tutela de urgência para quase todos os processos e procedimentos, a exemplo da ordonnance 
de requête e de refere, que poderão ser deferidas antes ou no curso do processo principal (FUX, 1996, p. 172). No Direito Processual francês, é grande a preocupação da urgência, e a "exposição de motivos do Code de Procédure afirma que existem circunstâncias nas quais o prazo de um só dia, ou de horas, pode apresentar a origem das maiores injustiças e causar perdas irreparáveis", mas a doutrina francesa reconhece a dificuldade em avaliar a urgência diante da questão fática (FUX, 1996, p. 173).

O Código de Processo Civil português prevê os procedimentos cautelares entre os artigos 381 e 392, bem como os procedimentos cautelares específicos: restituição provisória de posse, suspensão de deliberações sociais, alimentos provisórios, arbitramento de reparação provisória, arresto, embargo de obra nova e arrolamento (entre os artigos 393 e 427). O procedimento cautelar no Direito português assemelha ao Código de Processo Civil brasileiro de 1973, ressaltando a necessidade de propor a ação principal no prazo de 30 dias, contados a partir da data em que tiver sido notificada a decisão que a tenha ordenado, bem como a especificação de procedimentos cautelares (o que não há no novo Código de Processo Civil brasileiro). No Código de Processo Civil português, não há a previsão da estabilização da tutela, prevista no Projeto de Lei.

O Direito Processual alemão e o anglo-americano contemplam apenas o poder geral de cautela. Segundo Luiz Fux:

Nos dispositivos pertinentes, a ZPO alemã dotou o juiz do poder de conceder medida provisória de segurança da coisa litigiosa, resguardando a utilidade da execução forçada, e um poder denominado mesmo cautelar, com o escopo de criar uma situação provisória quanto à relação litigiosa para evitar prejuízos de monta (§§935 e 940). (FUX, 1996, pp. 168-169)

Observa-se que o direito alienígena influenciou e influencia o Direito Processual Civil brasileiro na busca de soluções para a efetividade do processo. 


\section{Conclusão}

Os institutos da cautelar e da antecipação de tutela, inspirados no Direito italiano e no Direito francês, visam solucionar uma limitação da técnica processual quanto à impossibilidade de aplicação instantânea do Direito na resolução do conflito. Dessa forma, toda a teorização dos referidos institutos objetivam atender à solução da falência, para alguns casos, do aspecto temporal ordinário do trâmite procedimental, vinculando-se ao estudo das urgências de tutela.

Existe uma confusão doutrinária entre a proposta de prestação jurisdicional célere e o estudo das tutelas de urgência. Apesar de os dois temas se vincularem a um tema comum, que é a efetividade do direito, o problema das urgências da tutela tem como formulação de solução os institutos do processo cautelar e da antecipação de tutela. Já a solução para uma prestação jurisdicional célere não está na ampliação de aplicação da concessão de medidas preventivas ou satisfativas, mas na observância, pelo Estado, do princípio da eficiência.

Ao contrário do defendido, percebe-se, com a previsão do instituto da tutela de evidência no projeto do novo Código, a nítida preocupação de se utilizar o processo cautelar e a antecipação de tutela para sumarizar o procedimento judicial, com decorrente sumarização de cognição. Ora, como formulado, a quebra da ordinariedade deve ocorrer em casos de urgência, como forma de superar a limitação do aspecto temporal do procedimento.

Outro ponto do trabalho foi a correta diferenciação entre medida cautelar e medida antecipatória, em que ficou clara a impossibilidade de fungibilidade entre uma e outra. Os próprios pressupostos para a concessão não são os mesmos, sendo inapropriado, como fez a comissão na elaboração do novo Código, tratá-las com possibilidade de fungibilidade.

Pretendendo-se alcançar a implantação de um Estado Democrático de Direito e considerando-se todos os avanços teóricos conquistados, pensa-se ser necessária a reformulação de várias disposições previstas 
no projeto do novo Código. Essa reformulação deveria corresponder a: dar tratamento diferenciado para as medidas cautelares e as antecipatórias, mantendo-se os pressupostos diferenciados, como previsto no Código vigente; repensar a possibilidade de fungibilidade entre as medidas cautelares e as antecipatórias; definir o alcance dos institutos, fixando o problema que cada qual visa a solucionar; e inibir a previsão do instituto da tutela de evidência, mantendo-se apenas a possibilidade de concessão de medida antecipatória, ausente a urgência, na hipótese de um ou mais pedidos serem incontroversos.

Dentre todas as previsões do tema no projeto do novo Código, talvez o único avanço técnico alçado que não represente afronta às bases teóricas aqui adotadas foi a possibilidade de estabilização dos efeitos da tutela. Veja que, nesses casos, é oportunizada à parte requerida que impugne a decisão. Diante da sua inação, é desnecessário o formalismo de se exigir o ajuizamento de procedimento pelo requerente, para que não ocorra cessão dos efeitos da lei adiantados na decisão.

Por fim, espera-se ter alcançado o objetivo pretendido com este artigo, na proposta de testificação das proposições apresentadas sobre tutela de urgência e tutela de evidência no projeto do novo Código de Processo Civil, restando a expectativa de que estas páginas possam contribuir para o aprimoramento da técnica processual e sejam capazes de ensejar maiores debates sobre o tema aqui tratado.

\section{Referências}

ALEXY, Robert. Teoria de los derechos fundamentales. Tradução de Ernesto Garzón Valdés. Madrid: Centro de Estudios Constitucionales, 1997.

ASSIS, Zamira de. A ideia da efetividade do direito nas urgências de tutela e as garantias constitucionais do processo. In: TAVARES, Fernando Horta (Org.). Urgências de tutela, processo cautelar e tutela antecipada: reflexões sobre a efetividade do processo no Estado Democrático de Direito. Curitiba: Juruá, 2007. v. 1. p. 179-188. 
BARACHO, José Alfredo de Oliveira. Direito processual constitucional: aspectos contemporâneos. Belo Horizonte: Fórum, 2006.

. Processo constitucional. Rio de Janeiro: Forense, 1984.

. Teoria geral do processo constitucional. Revista da Faculdade Mineira de Direito, Belo Horizonte, v. 2, n. 3/4, p. 89-154, $1^{\circ}$ e $2^{\circ}$ sem. 1999.

BARROS, Flaviane de Magalhães. O modelo constitucional de processo e o processo penal: a necessidade de uma interpretação das reformas do processo penal a partir da Constituição. In: MACHADO, Felipe Daniel Amorin; OLIVEIRA, Marcelo Andrade (Coord.). Constituição e processo: a contribuição do processo ao constitucionalismo brasileiro. Belo Horizonte: Del Rey, 2009. p. 331-345.

BARROSO, Luis Roberto. Curso de direito constitucional contemporâneo: os conceitos fundamentais e a construção do novo modelo. Rio de Janeiro: Saraiva, 2009.

BONAVIDES, Paulo. Curso de direito constitucional. 13. ed. rev. atual. São Paulo: Malheiros, 2002.

BRASIL. Constituição (1988). Constituição da República Federativa do Brasil. 11. ed. São Paulo: RT, 2009.

BRASIL. Lei $n^{\circ}$ 5.869, de 11 de janeiro de 1973. Institui o Código de Processo Civil. Diário Oficial da União, Brasília, DF, 17 de janeiro de 1973. Disponível em: <http://www.planalto.gov.br/CCIVIL/Leis/L5869. htm>. Acesso em: 25 out. 2010.

BRÊTAS, Ronaldo Brêtas de Carvalho Dias. Processo constitucional e Estado Democrático de Direito. Belo Horizonte: Del Rey, 2010.

. Responsabilidade do Estado pela função jurisdicional. Belo Horizonte: Del Rey, 2004.

CANOTILHO, J.J. Gomes. Direito constitucional e teoria da constituição. 3. ed. Lisboa: Almedina, 1999.

CARNELUTTI, Francesco. Como se faz um processo. Tradução de Hiltomar Martins Oliveira. Belo Horizonte: Malheiros, 2002. 
. Instituições do processo civil. Tradução de Adrian Sotero de Witt Batista. São Paulo: Classic Book, 2000. v. 1.

CHIOVENDA, Giuseppe. Instituições de direito processual civil. Campinas, SP: Bookseller, 2000. v.1.

CINTRA, Antônio Carlos de Araújo; GRINOVER, Ada Pellegrini; DINAMARCO, Cândido R. Teoria geral do processo. 9. ed. São Paulo: Malheiros, 1993.

COSTA, José Sarney de A. Projeto de Lei na Câmara n. ${ }^{\circ} 846$ de 2010. Dispõe sobre a reforma do código de processo civil. 2010. Câmara dos Deputados. Disponível em: <http://www.camara.gov.br/ proposicoesWeb/prop_mostrarintegra;jsessionid=339E2F0586BECE0 C325CF8DBAE4B0235. node2 codteor $=831805 \&$ filename $=P L+8046 / 2$ 010>. Acesso em: $1^{\circ}$ set. 2011.

COUTURE, Eduardo Juan. Las garantias constitucionales del proceso civil. In: ESTUDIOS de derecho procesal civil. Buenos Aires: Ediar, 1948. t. I.

DINAMARCO, Cândido Rangel. A instrumentalidade do processo. 10. ed. São Paulo: Malheiros, 2002.

FAZZALARI, Elio. Istituzioni di diritto processuale. 8. ed. Padova: A. Milani, 1996. confere?

FIX-ZAMUDIO, Hector. Constitución y proceso civil en Latinoamerica: estudios comparativos: derecho Latinoamericano. México, DF: UNAM, 1974. (Serie D. Numero 5).

FUX, Luiz. Tutela de segurança e tutela de evidência. São Paulo: Saraiva, 1996.

GONÇALVES, Aroldo Plínio. Técnica processual e teoria do processo. Rio de Janeiro: Aide, 1992.

HABERMAS, Jürgen. Direito e democracia: entre faticidade e validade. Tradução de Flávio Beno Siebeneichler. Rio de Janeiro: Tempo Brasileiro, 1997. v. I. 
- Três modelos normativos de democracia. Tradução de Anderson Fortes Almeida e Acir Pimenta Madeira. Cadernos da Escola do Legislativo, Belo Horizonte, p. 107-121, jan./jun. 1995.

LEAL, André Cordeiro. A instrumentalidade do processo em crise. Belo Horizonte: Madamentos, 2008.

LEAL, Rosemiro Pereira. Teoria geral do processo: primeiros estudos. 9. ed. Rio de Janeiro: Forense, 2010.

MACIEL JUNIOR, Vicente de Paula. Estrutura e interpretação do direito processual civil brasileiro a partir da Constituição Federal de 1988. In: MACHADO, Felipe Daniel Amorim; OLIVEIRA, Marcelo Andrade Cattoni de (Org.). Constituição e processo: a contribuição do processo ao constitucionalismo democrático brasileiro. Belo Horizonte: Del Rey, 2009. p. 293-311.

. Teoria das ações coletivas: as ações coletivas como ações temáticas. São Paulo: LTr, 2006.

MADEIRA, Dhenis Curz. Medida cautelar ex officio e legitimidade decisória. In: Tavares, Fernando Horta. (Org.). Urgências de tutela, processo cautelar e tutela antecipada: reflexões sobre a efetividade do processo no Estado Democrático de Direito. Curitiba: Juruá, 2007. v. 1. p. 61-77.

MARINONI, Luiz Guilherme. A antecipação da tutela. 3. ed. São Paulo: Malheiros, 1997.

NUNES, Dierle José Coelho. Apontamentos iniciais de um processualismo constitucional democrático. In: MACHADO, Felipe Daniel Amorin; OLIVEIRA, Marcelo Andrade Cattoni de (Coord.). Constituição e processo: a contribuição do processo ao constitucionalismo brasileiro. Belo Horizonte: Del Rey. 2009. p. 349-362.

- O princípio do contraditório: uma garantia de influência e de não surpresa. In: TAVARES, Fernando Horta (Coord.). Constituição, direito e processo. Curitiba: Juruá, 2008. p. 145-165.

. Processo jurisdicional democrático: uma análise crítica das reformas processuais. Curitiba: Juruá, 2010. 
OLIVEIRA, Manfredo de Araújo. A reviravolta lingüístico-pragmática na filosofia contemporânea. São Paulo: Loyola, 1996.

OLIVEIRA, Marcelo Andrade Cattoni de. Devido processo legislativo. 2. ed. Belo Horizonte: Mandamentos, 2006a.

. Poder constituinte e patriotismo constitucional: o projeto constituinte do Estado Democrático de Direito na teoria discursiva de Jürgen Habermas. Belo Horizonte: Mandamentos, 2006b.

Tutela jurisdicional e Estado Democrático de Direito: por uma compreensão constitucionalmente adequada do mandado de injunção. Belo Horizonte: Del Rey, 1998.

POPPER, Karl Raimund. Conhecimento objetivo: uma abordagem evolucionária. Tradução de Milton Amado. Belo Horizonte: Itatiaia, 1999.

. Sociedades abertas e seus inimigos. Tradução de Milton Amado. Belo Horizonte: Itatiaia, 1959. v. 1.

SILVA, Ovídio A. Baptista. Do processo cautelar. 3. ed. Rio de Janeiro: Forense, 2001.

SOARES, Carlos Henrique. Primeiras Considerações preliminares sobre o relatório do Novo Código de Processo Civil. Revista IOB de Direito Civil e Processual Civil, São Paulo, ano XI, n. 65, p. 119-113, maio/jun. 2010.

STRECK, Lênio Luiz. Constituição e processo, ou de "como discricionariedade não combina com democracia", o contraponto da resposta correta. In: MACHADO, Felipe Daniel Amorin; OLIVEIRA, Marcelo Andrade Cattoni de (Coord.). Constituição e processo: a contribuição do processo ao constitucionalismo brasileiro. Belo Horizonte: Del Rey. 2009. p. 3-27.

TAVARES, Fernando Horta. Tempo e processo. In: TAVARES, Fernando Horta. (Org.). Urgências de tutela, processo cautelar e tutela antecipada: reflexões sobre a efetividade do processo no Estado Democrático de Direito. Curitiba: Juruá, 2007. v. 1. p. 111-118. 
TAVARES, Fernando Horta et al. Urgências de tutelas: por uma teoria da efetividade do processo adequada ao Estado de Direito Democrático. Revista da Faculdade Mineira de Direito (PUCMG), Belo Horizonte, n. 21, v. 11, p. 145-162, 2008.

THEODORO JÚNIOR, Humberto. Constituição e processo: desafios constitucionais da reforma do processo civil no Brasil. In: MACHADO, Felipe Daniel Amorin; OLIVEIRA, Marcelo Andrade Cattoni de (Coord.). Constituição e processo: a contribuição do processo ao constitucionalismo brasileiro. Belo Horizonte: Del Rey, 2009. p. 233-263. - Primeiras observações sobre o projeto do novo código de processo civil. Revista IOB de Direito Civil e Processual Civil, São Paulo, ano XI, n. 66, p.7-12, jul./ago 2010.

ZAVASCKI, Teori Albino. Antecipação da tutela. São Paulo: Saraiva, 1997.

Recebido em: 19/03/12

Aprovado em: 10/05/12 